\title{
THE PROTECTION OF MINORITY LANGUAGES AT THE EUROPEAN LEVEL
}

MARÍA ACRACIA NÚÑEZ MARTÍNEZ 


\section{SUMMARY}

1. INTRODUCTION. 2. THE PROTECTION OF MINORITY LANGUAGES WITHIN THE EUROPEAN UNION. 3. THE PROTECTION OF MINORITY LANGUAGES OUTSIDE THE EUROPEAN UNION FRAMEWORK. 4. CONCLUSIONS. 


\title{
THE PROTECTION OF MINORITY LANGUAGES AT THE EUROPEAN LEVEL
}

\author{
MARÍA ACRACIA NÚÑEZ MARTÍNEZ \\ Profesora Contratada Doctora de Derecho Constitucional (UNED)
}

\section{INTRODUCTION}

The current EU comprises a territory in which linguistic diversity is a defining feature ${ }^{1}$, with 23 official recognized languages in addition to various regional languages ${ }^{2}$, that enjoy varying degrees of Constitutional protection inside each Member State ${ }^{3}$. In this regard it is worth noting the co-official status granted by the Spanish Constitution of $1978^{4}$ to Galician, Basque ${ }^{5}$ and Cata$\operatorname{lan}^{6}$ as compared with the lack of recognition accorded to Catalan and Basque by the French Constitution.

The EUROMOSAICO report ${ }^{7}$ states that the number of minority languages used within the European Union amounts to 36, and that these

1 SIGUÁN, Miguel: La política lingüística de la UE. Real Instituto Elcano. Documento de trabajo n. ${ }^{\circ}$ 39. 2004.

BRETON, R: Geografía de las lenguas. Oikos-tau ediciones. Barcelona. 1979.

3 DE WITTE, B: «Linguistic Equality. A study in Comparative Constitutional Law» in Llengua I Dret, $n^{\circ}$ 6. Barcelona. 1986.

4 ALCARAZ RAMOS, M: El pluralismo lingüístico en la Constitución española. Congreso de los Diputados. Madrid. 1999.

5 COBREROS MENDAZONA: El régimen jurídico de la oficialidad del Euskera. Instituto Vasco de Administración Pública. Oñati. 1989.

6 AGIRREAZKUENAGA, I.: Diversidad y convivencia lingüística. Diputación Foral de Gipúzcoa. Donostia-San Sebastián. 2003.

7 The EUROMOSAICO has its origin in the XXII General Convening of the European Commission (DG XXII) for the purposes of designing a plan to reflect the real situation of the 
comprise some 60 language groups, each receiving differing degrees of constitutional recognition ${ }^{8}$, but having one factor in common; that none enjoy official status 9 .

Over 40 million EU citizens use these regional languages ${ }^{10}$ to a greater or lesser extent, as well as the official language of the State. However, not all states in which regional languages coexist with national ones have granted them coofficial status. While Spain ${ }^{11}$, Italy, UK, Ireland, Finland, Luxembourg and Malta have done so; other states do not provide legislative recognition to all the languages spoken in their territory, thus co-official status is not recognized. These states include France, Poland, Greece and Bulgaria. The Belgian case is more complex, since the state is divided into linguistic political areas.

There is a great deal of difference between the treatment accorded to the official languages of the EU as compared to those that are not; official linguistic status guarantees two rights, namely the right to send documents to the Community institutions and to be answered in the same language, and that regulations and other legislative documents — in addition to the EU's Official Journal — be published in these languages; even if the official language is in practice used by a very small number of speakers, as is the case with Ireland, because Irish is considered the official language of the Republic of Ireland ${ }^{12}$.

so-called EU «minority languages», given the limited information that was available about the issue. The institutions responsible for this Project included: El Institut de Sociolinguiustica Catalana in Barcelona; the Centre de Recherchesur le plurilinguisme, based in Brussels, Belgium; and the Research Centre of Wales, located in Bangor, North Wales. The report praises the tendency to consider the existence of minority languages as something positive and as being fundamental with reference to diversity. The report was published by the Commission in 1996, with the title of Euromosaic: production and reproduction of the minority language groups of the $E U$, and later included more than 50 additional reports on the different linguistic communities in the Union.

8 Among all the EU minority languages three stand out in terms of the protection afforded to them by the domestic law of the State in which they are spoken, both because of the number of speakers, as well as the development of the territories in which they are located, such is the case with Catalan, Basque and Luxembourgish, which while not considered official languages under the EU Treaty, nevertheless are included in the total linguistic programs undertaken within the EU.

9 ROMAINE, S., «The impact of Language Policy on Endagered languages», in Unesco Most Journal on Multicultural Societies: Protecting Endagered Minority Languges: Sociolinguistic Perspectives, Vol. 4, nº 2. 2002.

10 GIORDAN, H. (ED.): Les minorités en Europe. Droits Linguistiques et Droits de l'Homme. Kimé. Paris. 1992.

11 BASTARDAS, A y BOIX, E (eds): ¿Un estado una lengua?. La organización política de la diversidad lingüística. Octaedro. Barcelona. 1994.

12 From 2005, it was decided that Irish be included as a working language within the Union, in operation such since January 1, 2007; though Irish is only used by a very small minority of its citizens. 
In the case of a language that is not considered official — even though it may be widely spoken - its speakers have no recognized right or recourse to the EU institutions in their native tongue, although this language may be recognized within the Member State.

Regarding the number of citizens who routinely use both official and minority languages there are major differences:

1) Those languages used by over 10 million people, all of which enjoy official linguistic status : German, the language normally used by over 90 million people in Europe and the official tongue in Germany and Austria, and the language of minority populations in France, Italy and Belgium; French used by 60 million; English by 64 million; Italian by 58 million; Spanish spoken by about 40 million; and Polish by 39 million all with the EU.

2) Languages spoken by between one to 10 million people. These include both official languages and those with minority status: Bulgarian, spoken by more than 8 million, is an official language; Catalan spoken by about 7 million is a minority language, although designated with co-official status by some $\mathrm{Au}-$ tonomous Communities in Spain and considered a minority language in France, Italy and Andorra; Slovakian spoken by 5 million, an official language; Finnish spoken by more than 5 million and an official language in Finland and spoken by a minority of approximately 300,000 people in Sweden; Danish 5 million, an official language; Lithuanian 3.7 million, an official language; Latvian an official language spoken by about 2 million; Galician a minority language spoken by about 2 million, although granted co-official in the Autonomous Community of Galicia; more than 2 million Occitan speakers a minority language in parts of Spain, France and Italy; Sardinian a minority language of more than 1 million speakers in Italy; Irish with about the same number of speakers and the official language of the Republic of Ireland and a minority language in the UK...

It is noteworthy that some minority languages such as Catalan and Galician possess a much larger number of speakers than some official languages, this is the official reason for the Catalan authorities request — with the support of the Spanish State - that Catalan be given more equal treatment in line with official EU languages, though this has not happened so far.

3) Languages spoken by less than a million people include: Basque (used by some 683,000). The treatment given to this language differs greatly in Spain and France; whereas in Spain, it is considered a minority language, and has co-official status in the Basque Autonomous Community and in the Basque 
speaking area of Navarra; in France, however, Basque has no official protection whereas its status in Spain is fully guaranteed.

4) Other minority languages that are spoken by less than a million people include: Welsh with 508,000 speakers, a minority language in the UK; Maltese 400,000; Frisian 400,000, a minority language in the Netherlands and Germany; Friulian a minority language with 400,000 speakers in Italy; Luxembourgish 350,000, spoken in Luxembourg; and the Breton and Corsican minorities in France with 180.000 and 125,000, speakers respectively...

Languages used by temporary or permanent immigrants to the $\mathrm{EU}^{13}$, as noted by SIGUÁN ${ }^{14}$. In the case of the non-EU resident population in some states, for instance France, where the sizeable Arab population routinely use Arabic to communicate and exceed the speakers of some native minority languages such as the Alsatian or Breton.

It is far from easy to make a confident calculation of the number of speakers of each language, given that some languages play two distinct roles, being official languages in some EU states, but a minority tongue in others, as for instance with German, the official language of Germany and Austria, but a minority language in France, in its Alsatian variety, and in Belgium ${ }^{15}$.

\section{THE PROTECTION OF MINORITY LANGUAGES WITHIN THE EUROPEAN UNION ${ }^{16-17}$}

The first prerequisite to an analysis of the protection granted to linguistic minorities is to establish what is meant by minorities. It was not until 1979

13 GRIN, F., «Combining inmigrant and authoctonous language rights: a territorial approach to multilinguanism» in SKUTNAB-KANGAS T and PHILIPSON R (EDS): Linguistic Human Rights. Overcoming Linguistic Discrimination. Mouton de Gruyter. Belin/New York. 1995.

14 See SIGUÁN, Miguel: ob.cit. above n.1 at p. 2 and ff.

15 As noted by PIERGIGLI, V., «Las minorías lingüísticas en el ordenamiento italiano», in Revista de Derecho Politico; as a result of the initiatives undertaken by the Council of Europe and with state co-operation, bi-or multilateral regulation of linguistic minorities has been implemented, as well as cross-border cooperation measures. For instance the 1992 Italian-Croatian-Slovenian «Memorandum of Understanding»; the Croatian-Italian Treaty of 1996 (ratified by Italy by Law 129/1998, regulating the condition of the Italian minority in Croatia. See Ronzitti, N: «Il trattato tra Italia e sulle minoranze Croazia» in Riv. Dir.Internazionale No. 3, 1997, p. $684 \mathrm{ff}$.

16 See VVAA: Drets linguistics a la nova Europa (II Simposio Internacional de Lenguas Europeas y Legislaciones), Ciemen-Editorial Mediterránea. Barcelona. 1996.

17 NIC SHUIBHNE, N., «The European Union and Minority language rights» in Unesco Most Journal on multicultural societies. Vol. 2, $\mathrm{n}^{\circ}$ 2. 2001. 
when the Special Reporter of the United Nations and Chairman of the Subcommittee Francesco Carpotori ${ }^{18}$ provided the following definition:

«A minority is a group numerically inferior to the rest of the population of a state (...) whose members — despite being nationals of the State- possess distinct ethnic, religious or linguistic characteristics that are distinct from the rest of the population and who, even if only implicitly, maintain a sense of solidarity, directed towards preserving their culture, traditions, religion or language.»

This definition was the foundation for other subsequent formulations, that have respected Caportori viz. those elements that allow us to define what amounts to a minority. These include the numerical factor, and those differentiating features relative to the rest of the State's inhabitants, along with the sense of belonging to this minority group, and the aspiration to preserve those elements that set them apart from the rest. Other authors such as Pizzorusso ${ }^{19}$, inter alia, indicate that minority language communities are those that are in a diffused state, who persist over time, whose presence in the community arises voluntarily, who lack legal status, whose numbers are significantly lower than the rest of the state's population, and who maintain, promote and disseminate characteristics and differentiating aspects that single them out as belonging to a minority.

The protection at a Community level of minorities across the board and of particular linguistic groups in particular was not an EU priority at the outset, given that the process of European construction was influenced by other economic or political factors that took first priority. Granting rights to minorities was largely ignored in both the founding and subsequent EU treaties, with the exception of the 1992 Maastricht Treaty ${ }^{20}$, this document represents a turning point as regards the recognition of minority rights at the community level. Subsequently in 1993, the Presidential Conclusions of the Copenhagen European Council held on the 21 and 22 June 1993, determined that any State seeking admission into the Union was under an obligation to demonstrate its commitment to protecting minority rights in its territory; this requirement

18 CARPOTORI, F., «Estudio de los derechos de las personas pertenecientes a las minorías étnicas, religiosas y lingüísticas», in $D o c E / C N .4 / S u b 2 / 1979 / 384$, Publications of the United Nations, Geneva. 1979.

19 See PIZZORUSSO, A., Le minoranze nel dirittopubblico interno. Milán, 1967, pp. 126 and ff. Also «Minoranze etnico-linguistiche», in Dir. XXVI, Milán. 1976. pp. 531 and ff.

20 The Treaty refers directly to the cultural and linguistic richness that are essential elements of national identity. Specifically, Article 128 (151 of the consolidated version) states that: «the Community shall contribute to the flowering of the cultures of the Member States, while respecting their national and regional diversity, highlighting both the common cultural heritage». 
has since a become a sine qua non of EU membership. From the 1990s onwards there has been a major shift in the attitude of the EU to protecting minority rights $^{21}$. In addition Community commitment to aspects of cultural protection is now enshrined in Article 167 of the Treaty on the Functioning of the European Union, which in turn contains the provisions previously set forth in provision 151 of the Treaty of the European Community (TEC).

In accordance with The Treaty on the Functioning of the EU in the field of culture, the EU does not adopt any specific policy, though as a matter of practice it offers its full support and encouragement to whatever Member State policies are adopted in this area; this is fully in line with the principle of subsidiarity which governs all such areas, favoring action at a Member State level except in those areas that fall within the exclusive competence of the EU.

At the institutional level since the early $1980 \mathrm{~s}^{22}$, the European Parliament has worked to raise awareness of minority languages as an expression of the multiculturalism in which the Union is immersed. Among the measures worth highlighting is the EU commitment to encouraging educational policies designed to improve or promote the teaching of languages at all levels of education $^{23}$, the dissemination of minority culture, and the implementation of

21 CORRETJA I TORRENS, M., L'acció europea per a la protecció dels drets lingüístics. Generalitat de Catalunya. Barcelona. 1995.

22 The European Parliament on October 16, 1981 adopted a Resolution dealing with the future adoption of a Community Charter on regional languages and cultures, and a Charter on the Rights of Ethnic Minorities (OJ C 287, 09.11.1981. P .106). These Resolutions were followed by others; e.g. that of 11.021983 , on measures to be adopted to achieve both the promotion and protection of languages and minority cultures. (OJ C 68, 14.3.1983, p. 103); that of 30.10 .1987 , on the languages and cultures of regional and ethnic minorities in the European Community (OJ C 318, 30.11.1987, p. 160); the 11.12.1990 Resolutions on the status of languages in the Community and the Catalan language (OJ C 19 28.1.1991.p. 42); Resolution of the 09/02/1994, on cultural and linguistic minorities in the European Community (OJ C 61, 28.2.1994 p. 110); and the Resolution of 13.12.2001, on European regional and lesser known languages (OJ C $177 \mathrm{E}, 25.7 .2002$ p. 334).

23 Among the measures that States can take to benefit from specific budget line B3-1006 worth noting are: undertaking innovative pedagogical projects at all levels of education; training programs and piloting teachers at any level, including specific adult learner education; the publication of teaching materials in the minority language for later use in the classroom training; the work of language standardization, lexicological and terminological organizing courses, workshops and seminars; the implementation of innovation networks. The projects undertaken must be linked to the use of ICT and new technologies. In the case of educational projects it is necessary to specify the specific methodology to be used, evaluative criteria, the number of hours and the students involved... 
information and experience between all institutions involved in the safeguarding the languages used in the Union ${ }^{24}$.

In this regard one cannot fail to mention several EU resolutions adopted to support these goals. For instance resolutions inspired by the Arfe reports (Community Charter on the Rights of Ethnic Minorities) and (Measures in favor of minority languages and cultures) dating back to 1981 and $1983^{25}$ respectively; the Kuijpers report of 1987 (Languages and cultures of regional and ethnic minorities in the European Community); the Reding report of 1991 (The status of languages in the European Community and of the Catalan language); the 1994 Killilea report (the «Killilea Resolution» The cultural and linguistic minorities of the European Community). This technical paper recognized the Valencian, as a distinct language from the Catalan as well as the proposed Morgan Resolution of 2001 (B5-0537/01) on minority languages .

The European Parliament session of May 15, 2003, authorized the Committee on Culture, Youth, Education, Media and Sport to draft an initiative legislative report, pursuant to the provisions of Regulation 59 and 163 on European regional and lesser-used languages. The report was released on July 14, $2003^{26}$. This document included a series of recommendations to the Commission concerning less widely used European and regional languages - the languages of minorities in the EU in the light of enlargement and cultural diversity $\left(2003 / 2057(\text { INI })^{27}\right.$.

In 1982 the decision was taken to found the Office of European Minority Languages (OEML) an institution representing all minority languages within the Union, which on being endowed with its own budget, carried out the necessary task, of promoting and protecting minority languages. However, a 1998 ruling handed down by the ECJ — in the case C-106/96 of May 12, 1998- effectively suspended this financial support, on the basis that such EU finance had to have a prior legal basis, which in the judgment of the Court had not been provided in this case.

The Commission, for its part, as part of its efforts to promote the protection of regional and minority languages has subsidized various projects, whose

24 O RIAGAIN, D., «The European Union and lesser used languages» in Unesco Most Journal on multicultural societies: lesser used languages and the law in Europe, vol. 3, n. . 1. 2001.

25 Following this Resolution, the Commission opened a specific budget line in 1983. This line was the B3-1006.

26 European Parliament. Final Session Document A5-0271/2003. RR/503926ES.doc

27 That same year a Resolution was approved, namely that of January 14 about the role occupied by regional and local authorities in European (2002/2141 (INI), which highlighted the existing linguistic diversity within the Union. 
ultimate goal is to achieve a rapprochement between the official and minority languages, embracing in the process both state and community institutions.

Among the projects worth highlighting is the ADUM (2004-2005), which provides information about funding opportunities available to institutions that perform tasks on behalf of regional and minority languages in the EU. Equally the pan-European network to promote linguistic diversity (NPLD) encompasses those minority and regional languages, that are spoken in one or more Member States, and takes various measures to protect European multilingualism, and helps to connect various institutions working to achieve the implementation of minority language recognition, and to facilitate their closer integration in order to create a forum for presentations and exchange of ideas, information and best practices in order to improve their overall situation .

Worthy of note, is the work done by Committee of the Regions, and the Commission's cooperation with those institutions that protect linguistic minorities in the EU, most notably the work carried out by the Network for promotion of linguistic diversity (Network to Promote Linguistic Diversity-NPLD), and the collaboration that has been taking place with the European Office for Lesser Used Languages (European Bureau for Lesser Used Languages-EBLUL), before it finally disappeared, as well as MERCATOR network, which does remarkable work in matters affecting specific conflicts involving minorities. It is also essential to mention the specific policies affecting several regions, such as the Danube Strategy, and the Convention for the Protection of the Alps.

The Charter of Fundamental Rights of the European Union (2010/ C 83/02), text supra that includes adapting it the Charter of Fundamental Rights of the European Union (2000 / C 364/01), is the document referred to in Article 6 of the Lisbon Treaty, which provides that the Union recognizes the rights, freedoms and principles contained in the Charter of Fundamental Rights of the European Union of 7 December 2000, and that its provisions have the same legal status as the Treaties.

Regarding its interpretation, the Treaty states that all the rights, freedoms and principles in the Charter shall be interpreted in accordance with the general provisions of Title VII of the Charter. It also ratified the accession of the Union to the European Convention on the Protection of Human Rights and Fundamental Freedoms.

The Preamble sets forth the Union's contribution to both the development and the preservation of shared values, always with respect to the cultural heterogeneity of the various peoples contained within it. 
In Chapter III, under the heading Equality, principles 21 and $22^{28}$ are of particular note and are applicable to the theme of this article. Article $21^{29}$, under the heading non-discrimination, prohibits any form of discrimination:

«based on gender, race... tongue... or belonging to a national minority...; conducted by any institution or agency of the Union, when exercising powers derived under Community law, or by any Member State when they are implementing Union law to those who are permanently or temporarily in a Member State of the Union $»^{30}$.

This clearly reflects influences characteristic of natural law, which links the enjoyment of these rights to the concept of human dignity, as is clearly stated in principle 21. Principle $22^{31}$ for its part governs Cultural, religious and linguistic diversity and advocates equal respect for cultural as well as religious and linguistic diversity.

28 VVAA: El dret a la diversitat lingüística. Reflexions al voltat de l'article 22 de la Carta dels Drets Fonamentals de la Unió Europea. Ciemen-Editorial Mediterránea. Barcelona. 2002.

29 The Charter explanations initially drafted under the auspices of the Praesidium of the Convention drafting the Charter of Fundamental Rights of the EU, and subsequently updated by the Praesidium of the European Convention, the text - following the adjustments made by the Convention - is an important interpretative document, which greatly facilitates the sense that is to be given to this Declaration. Article 21 provides that is based on Articles 13 of the Treaty Establishing the EC; on Article 19 of the Treaty on the Functioning of the EU; on Article 14 of the ECHR; and Article 11 of the Convention on Human Rights and Biomedicine. Meanwhile sleeves, A, in Charter of Fundamental Rights of the European Union. For his part, Mangas A.in Carta de los Derechos Fundamentales de la Unión Europea. Comentario artículo por artículo, ( Mangas A, as coordinated by González A, BBVA Foundation, 2008), at p. 396 outlines the history of this article and states that is based on the items corresponding to the current version of the TEU and the TEC (Articles 12 and 13 TEC), as well as on Article II-81 of the Treaty establishing a Constitution for Europe. Mangas also claims that he can relate Articles 20, 22-26 and 52 of the Charter, to Articles 2 and 3 of the TEU and Articles 10, 18, 19, 157 and 199 of the TFEU.

30 As Mangas A points out, op.cit. above n. 15 at p. 399, to see the extent of the application of this right to EU citizens see Oyowe and Traore c. Commission, C-100/88, paragraph 16.

31 The protection that Article 22 grants to the cultural field has its source in Article 6 TEU, 151 paragraphs 1 and 4 of the EC Treaty, in paragraphs 1 and 4 of 167 of the Treaty on the Functioning of the EU. Respect for cultural and linguistic diversity is based on the third paragraph of Article 3 TEU. Mangas, op cit.. above n. 15. at p. 409, notes that the history of this article is to be found in Article 6 TEU, at 151 TEC in the Declaration No 11 of the Final Act of the Amsterdam Treaty on the Status of churches and non-confessional organizations, and in Article II-82 of the Treaty establishing a Constitution for Europe. With regard to the provisions relating to this article Mangas mentioned second and third paragraphs of the preamble of the Charter, as well as Articles 21 and 52. Also, see reference the third paragraph of the Preamble, and Articles 2, 3.3, 4 and 31 of the TEU, and finally to Articles 10 and 19 TFEU. Regarding the protocols and declarations see Declaration 61 of the Republic of Poland on the Charter of Fundamental Rights of the European Union. 
All Community institutions and bodies are obliged to respect, within the scope of their powers, the provisions contained in this document, and Member States $^{32}$, in situations where Community law is applicable, must always do so in a manner that insures that the protected rights, are not misinterpreted and violated in any way.

In cases where it is necessary to limit any rights enshrined in the document, the limitation shall be made in a manner that fully respects the essence of the right so regulated, with the result that after the limitation, the said rights are not subject to misinterpretation so as to deprive them of the essential character that preserves their recognition. In all cases, any limitation of a right shall be imposed in accordance with the principle of proportionality, on the assumption that the public interest so requires, or to guarantee the enjoyment of third party rights.

The Union and the Council of Europe jointly determined that the year 2001 was declared the European Year of Languages ${ }^{33}$, and the expression "of the languages» embraced all the languages used, both official and minority. The Union sponsored the project whose aim was to spread these lesser used languages, but in line with the 1998 judgment cited above, the financial backing of the EU Parliament was no longer available. On 16 June 2001 the Committee of the Regions adopted an Opinion on the promotion and protection of regional and minority languages in which it stressed that:

«any European Union action in the field of language policy should guided by the objectives of conservation, intergenerational transmission, utilization, and quality promotion of regional and minority languages.»

The Committee also stated that:

«as language permeates all aspects of life of the people by its range and significance, language issues should be at the forefront in all areas of policy formulation and implementation.»

32 States only have to respect the rights that are regulated by Community law in the course of applying EU law, as is clear from the jurisprudence of the Court in the judgments on July 13, 1989, Wachauf case 5 / 88, ECR 1989, p. 2609; of June 18, 1991, ERT, ECR 1991, p. I-2925; of December 18, 1997, Annibaldi C-309/96, ECR 1997, p. I-7493; of April 13, 2000, Case C-292/97, ECR 2000, p. I-2737, paragraph. 37. Finally, note that what applies to a centralized state is likewise equally applicable to both authorities integrated into a federation as well as to regional or regional bodies in the case of highly decentralized states composed of regions with a greater or lesser degree of decentralization, in the case of the Community law to be applied, and this includes public or local bodies.

33 Following the adoption of decision number 1934/2000CE the European Parliament and of the Council of July 17, 2000, which was declared European Year of Languages 2001. DOL232, 14.9.2000. p 1. 
On the 14 February 2002 the Council adopted a Resolution ${ }^{34}$ aimed at protecting linguistic diversity, while leaving to the Commission the task of promoting the learning of languages used within the Union.

The Lisbon Treaty places respect for cultural and linguistic diversity as an aspect of vital importance for the protection of the EU's cultural heritage, enshrining a Fundamental Rights Charter, which condemns all forms of discrimination against minority membership, or the use of any language.

The Committee of the Regions adopted an opinion on the:

«protection and development of historical linguistic minorities under the Lisbon Treaty» (2011 / C 259/06).

It identifies the positive effects of European linguistic diversity, and welcomes the development of Community law, in particular the Lisbon Treaty, which establishes respect for the richness of cultural and linguistic diversity as a key element in the development of European cultural heritage, and the Charter of Fundamental Rights, which prohibits any form of discrimination based on language and membership of a national minority.

Yet there remains much work to be done, as the opinion of the Regional Committee makes clear in their requests to the Commission not to relent in its efforts to promote diversity, and to continue taking steps to ensure that the teaching and promotion of languages, especially the minority ones is implemented.

The Committee continues to make recommendations that fully acknowledge the linguistic diversity within the EU territories and when to take action. Although it is commonly accepted that Member States have their own discretion in the adoption of educational, and cultural matters... nevertheless the decisions of the Court of Justice of the European Communities (ECJ), has made it clear that in cases where Member States through their legislation or actions come to violate the principles of the free movement of persons, equality or the scope and limits of national policies to promote language rights; in such circumstances such state discretion must be limited in order to protect and grant due recognition to linguistic rights. (See Case 379/87 ECJ, in favor of defending Irish against the freedom of movement of workers, and Mutsh Issue 137/84 of July 11, 1985.)

34 This Resolution must be framed in the context of fulfilling the objectives of the European Year of Languages. DOC 50, 23.2.2002. p.1. 


\section{THE PROTECTION OF MINORITY LANGUAGES OUTSIDE THE EUROPEAN UNION FRAMEWORK ${ }^{35}$. ESPECIALLY WITH REGARD TO THE WORK OF THE COUNCIL OF EUROPE ${ }^{36-37}$.}

The European Charter for Regional or Minority Languages ${ }^{38}$ was adopted on June 25, 1992 with the status of Convention by the Committee of Ministers of the Council of Europe.

It was ratified in the French city of Strasbourg, on November 5, 1992 by Member States of the Council of Europe, and has been in force since 1998. The Charter ${ }^{39}$ provides a definition in Article I of what we understand by regional or minority languages ${ }^{40}$ indicating that they are systematically used at the state level by a minority of its citizens, that they are not dialects, and are not languages used by nationals of third countries who happen to be located in the State as a result of migration. The purpose of this document is to protect those languages that, lacking official status, are used in the Member States, including those that possess official status in some Member States but they are a minority language in others, with the aim of thus contributing to the

35 DEOP MADINABEITIA, X., «Los derechos lingüísticos en el Derecho Internacional» in Llengua i Dret, $n^{\circ} 33$, pags. 23-45. Barcelona. 2000.

FERNÁNDEZ LIESA, C.R., Derechos lingüísticos y Derecho Internacional. Dykinson/Universidad Carlos III. Madrid. 1999. First monograph that has an impact on the systematic study of the relationship between minorities and international law.

36 DEOP, X., La protección de las minorías nacionales en el Consejo de Europa. San Sebastián. 2000. Work that provides a complete view of the protection granted in the scope of the Council of Europe to minorities.

37 VACCA, A., «A comparative approach between the Council of Europe Treaties and the European Union Framework in the legal protection of minority languages», in Llengua I Dret $\mathrm{n}^{\circ} 53$. Pags. 111-136. 2010. Essential work carried out a in-depth study among regulations approved at the hearth of the Council of Europe and the European Community.

38 See PETSCHEN, S., «La Carta Europea de las lenguas regionales y minoritarias», in Revista de Estudios Políticos, n ${ }^{\circ}$ 66, 1989, pp. 127 and ff.

39 VVAA (RUIZ VIEYTEZ, E.; UNAMUNO, V.; ETXEBARRÍA, M.): Carta Europea de las Lenguas Regionales o Minoritarias. Una perspectiva sobre su aplicación. Euskara Kultur Elkargoa. Pamplona. 2003. This collective work is a systematic study of the Charter.

40 As says RUIZ VIEYTEZ, E., in «Lenguas oficiales y lenguas minoritarias: cuestiones sobre su estatuto jurídico a través del derecho comparado», en II Mercator International Symposium: Europe 2004: A new framework for all languages? Tarragona. Cataluña. 2004. The Charter provides four new categories of languages, official languages, regional and minority languages, nonterritorial languages and «less widely used» official languages. Official and minority languages have been defined in the text. The non-territorial are those hardly identifiable with a particular territory of the State and the official «less widely used» are the official minority used, as it is the case of the Swedish in Finland or Gaelic in Ireland. 
maintenance and development of Europe's cultural wealth. In the preamble to the Charter it is stated that:

«the right to practice a regional or minority language in private and public life is an inalienable right.»

The protection afforded by the Charter (the only binding document that protects minority languages) does not extend to dialects of the official languages $^{41}$, nor to the languages used by the immigrant communities located in any Member State.

The Charter leaves it to each State to ratify the language or languages that they undertake to protect, and the manner of such protection, in addition on signing, ratifying or accepting the Charter the Member States are entitled to make reservations in accordance with sections 2-5 of Article 7.

Language diversity is an essential part of European identity, and protection and dissemination is a task that can best be carried out in the main by the Member States; thus in recent decades, in line with agreements such as the Charter, national authorities have taken decisive steps in order to ensure no loss of the idiosyncratic elements that so enrich both the Member States and Europe itself.

Member States, on signing the Charter, enter into a number of commitments aimed at preventing the introduction of any kind of barrier or impediment linked to the use of minority language learning, thereby fostering respect for them, but always making clear the need to know the official language of the State in which they reside. Only by these means can full integration of minority language speakers be achieved with equal conditions, and bearing in mind that the right to the use of regional or minority languages both in private life and in public is a right laid down by the United Nations in the International Convention on Civil and Political Rights and is also in line with the spirit of the Convention for the Protection of Human Rights and Fundamental Freedoms of the Council of Europe. In the same vein we must not forget the work of the CSCE (named later OSCE) in this field, nor the provisions of the Helsinki Final Act of 1975, or the document adopted in Copenhagen in 1990.

$41 \quad$ Dialects are understood as language systems based on another language but which lack sufficient substantial differences so as to be considered a different language. 
The following Member States have ratified the document and determined those languages eligible for state protection and those which have been excluded. Germany ${ }^{42}$, Austria ${ }^{43}$, Belgium ${ }^{44}$, Bulgaria ${ }^{45}$,Czech Republic ${ }^{46}$, Cyprus $^{47}$, Denmark $^{48}$,

42 Date of signature 5/11/92. Date of ratification 16/09/98. In force since 01/01/99. Protected minority languages: Danish (used in Schleswig-Holstein and protected in the Declaration of the Government of Schleswig-Holstein on September 26, 1949, in the article 5 of the Land Constitution and in the Bonn Declaration of 1955), High Saxon (used in Saxony), Lower Saxon (used in Brandenburg); Friesian (used in Schleswig-Holstein and Lower Saxony) Law German (used in Bremen, Hamburg, Mecklem, Burgo-Western Pomerania, Lower Saxony and Sahleswig-Holstein). The Roman, the Sinti (of German nationality in the federal regions of Brandenburg; Rhineland / Westphalia; and Saxony-Abhalt. Upper Sorbian Language (Brandemburg, and Saxony. This language can be considered as a cooficial in some districts. It is protected under the 1990 Unification Treaty). Minority languages excluded from protection: Roma and Luxembourgish. The German Constitution does not allow discrimination on linguistic grounds (art. 3).

43 Date of signature 5/11/92. Ratified on the 28/06/2001. In force since the 01/10/2001. Protected minority languages: Croatian (used in Burgenland. In this area of the country CroatianGerman bilingual schools have been established, but in many of them the priority is the German language, though there is an obligation to ensure the teaching of at least three hours of Croatian each week); Slovenian (used in Carinthia and Styria) Hungarian (used in Burgenland and Vienna) Czech (used in Vienna); Slovak (used in Vienna) Roma (used in Burgenland. In Austria there are some 30,000 Croatian speakers, some $0.4 \%$ of the population, the majority of which, about 19,000, are concentrated in Bungenland. The Austrian Constitution does not allow discrimination on the linguistic grounds in the field on education (art. 14). In the article 4 includes an official language.

44 Have excluded Luxembourgish from protection. The Constitution in some of the articles refers to a subsequent law that regulates the status of languages. Article 4 of the Belgian Constitution declares the existence of three linguistic regions, and therefore declared the officiality of the French, Dutch and German in each.

45 ibid., Turkish and Roman. Have excluded Luxembourgish from protection. In any case, the Bulgarian Constitution says that all the citizens have to learn the official language (art. 36), and guarantees the right to receive education in their own languages (art. 36). Likewise the Constitution refers to a subsequent law that regulates the status of languages (art. 36).

46 Signature date 09/11/2000. Ratified on the 15/11/2006. In force since 01/03/2007. Protected minority languages: Polish (used in Moravia Silesia); Slovak. Roma has been excluded from protection. The Czech Constitution does not include any language question.

47 Signature date 12/11/92. Ratified on the 26/08/2002. In force since the 01/12/2002. Protected minority languages: Armenian. The Constitution does not allow discrimination on linguistic grounds (art. 28), and includes an official language in article 3.

48 Date of signature 5/11/92. Ratified on the 08/09/2000. In force since the 01/01/2001. Protected minority languages: German (used in Jutland). The Charter protection does not apply to Faroese (a language mostly used in the Faroe Islands), nor to Greenlandish (used in Greenland), which already enjoyed a ample guarantees at the time the Charter was signed. The danish Constitution does not include any language question but the law governing the autonomous communities of the Faroese and Greenland islands within the Kingdom of Denmark concerning the native languages of both territories. 


\section{Slovakia $^{49}$, Slovenia $^{50}$, Spain $^{51}$, Finland $^{52}$,}

49 Date of signature: 20/02/2001. Ratified on the 05/09/2001. In force since the 01/01/2002. Protected minority languages: Bulgarian, Croatian, Czech, German, Hungarian, Polish, Roma, Ruthenian, Ukranian. The Constitution does not allow discrimination on linguistic grounds (art. 12), and guarantees the right to receive education in their own language (art.34), the right to communicate to the institutions in their own language (art. 34). Likewise the Constitution refers to a subsequent law that regulates the status of languages (arts. 6, 26, 34) and includes an official language in article 6.

50 Date of signature: 03/07/97. Ratified on the 04/10/2000. In force since the 01/01/2001. Protected minority languages: Roma, Italian, Hungarian. The Slovenian Constitution guarantees the right to use own language freely (art. 61), the right to promote language is on the article 64. Likewise the Constitution refers to a subsequent law that regulates the status of languages (art.62) and includes an official language in article 11.

51 Date of ratification 5/11/92; signed on 09/04/2001.In force since the 01/08/2001. Catalan protected minority language (used in Catalonia, the Balearic Islands, Aragon); Valencian (used in Valencia, in the region of Murcia and Valencia border known as the «Carche» in Yecla and Abanilla Jumila and Aragon); Euskera (used in the Basque Country and Navarre-Basquespeaking area); Galician (used in Galicia); Occitan (used in Catalonia, particularly in the Aran valle where it is known as Aranese. Under Article 5 of the Statute of Autonomy of 2006, the Aranese language is considered co-official with Catalan and Castilian. In September 2010 the Parliament passed the Aranese Act. In September 10, 2009, the Government and the General Council d'Arán ratified an agreement pursuant to which in the Vall d'Arán priority is given to the Aranese language in the classroom); Asturian or Bable (used in Asturias); Leones (used in Castile and León), Aragonese (utilized in Aragón). Amazigh has been excluded from protection (used in Ceuta and Melilla), and the Leonese (used in Cantabria and Extremadura). In Spain there is a strong awareness of the need to provide legal protection for minority languages, as evidenced by the fact that both within the Constitution and pursuant to the Statutes ofAutonomy, a broad level of protection is granted to minority languages Likewise, the case law of the Constitutional Court supports the idea of protection, has it has made clear in Judgment 337/94, where the court stated that: «linguistic diversity as a manifestation of the wealth of cultural heritage is worthy of special respect and protection, assuming not only coexistence, but also cohabitation of both co-official languages to preserve bilingualism». In any case everybody have to study the official language (art. 3). The Constitutional Court has granted a definition in judgement 82/1986, of 26 june to point out that «is official language, regardless of its reality and presence as a social phenomenon when it is recognized by the public branchs as a normal means of communication in and between them and its relationship to private subjects with full force and legal effect». About the ratification of the Charter by Spain see CASTELLÁ, S.: La ratificació de l'Estat espanyol a la Carta Europea de llengues regionals o minoritaries. CIEMEN, Doc Treball 8. Barcelona. 2002.

52 Date of signature: 05/11/92. Date of ratification 09/11/94. In force since the 01/03/98. Minority languages protected Sami (in the article 17 of the Constitution this language is protected, and it is considered the official languages in some municipalities or districs); Swedish (this language is considered by the Charter a «less widely used official lamguage»); Roman; other languages without a specific territory. Carelio (used in Carelia) has been excluded from protection. Finnish municipalities, as determined by a law of the National Parliament, may be of two types, either monolingual (in whichever of the two official languages either Finnish and Swedish) in the case where the number of speakers of the minority language is only $6 \%$ or less (as for instance in 
France $^{53}$, Greece $^{54}$, Hungry ${ }^{55}$, Ireland ${ }^{56}$ Italy $^{57}$,

the case of the Aland islands), or fully bilingual, if at least $8 \%$ of the of the population or 3,000 people speak the local minority language, regardless of which of the two languages is concerned. For the bilingual municipalities, the Government has the obligation imposed by law, to provide all public services in both languages, although no one had asked. In Finland it is fair to say that bilingualism (Swedish-Finnish) is fully complete at all levels, all the streets are labeled in both languages, and all the documentation of official bodies, etc.. The finish Constitution does not allow discrimination on linguistic grounds (art. 6). Likewise the Constitution refers to a subsequent law that regulates the status of languages (art. 122). The national language is in article 17.

53 Date of signature: 07/05/1999. It has not been ratified. Minority languages excluded from protection: German; Breton; Catalan; Corsican; Euskera; Provencial French; Luxembourgish; Occitan; Roma. Unprotected minority languages spoken outside the European territory: Warao (used in French Guyana) Caribbean languages (used in San Martin); shimaore (used in Mayotte) Tamil (used in Reunion). The French Constitutional Council in its decision 99-412 of June 1999, previously upheld the appeal submitted by the President and stated that the Charter did not comply with the supreme law, and that it violated the principles related to the indivisibility of the Republic, as well as equality and the unitary character of the French people. It also undermined the constitutional proclamation of the official status of the French language. This decision is discussed by MELIN-SOUCRAMANIEN, F.: «La République contra Babel», in Rev. Do Público, $\mathrm{n}^{\circ} 4$. 1999, pp. 985 and ff. The Constitution includes the language of the Republic (art. 2).

Although France is not a state that advocates greater protection of minority languages. In 1994 it signed an agreement under the terms of which it was agreed that students in the German-speaking area would receive bilingual training from the age of three; which means that certain languages of the curriculum will be taught in French and others in German, so that on completion of their education students must achieve equal dominance of both languages.

54 There is no protection for Roma; Turkish; or Gagauz. Under the Treaty of Lausanne, the Turkish Muslims are considered a religious minority, and so can the competent authorities can teach the faithful so that they can go to the mosques and further religious services. For this reason they have founded schools in which students receive teaching in both languages, Turkish and Greek. The Constitution does not allow discrimination on linguistic grounds (art. 5).

55 Date of signature: 05/11/92. Ratified on the 26/04/1995. In force since the 01/03/1998. Protected minority languages: Croatian, German, Romanian, Serbian, Slovak, and Slovenian. Roma has been excluded from protection. The Constitution does not allow discrimination on linguistic grounds (art. 70), the protection of linguistic minorities is granted, and guarantees the right to use own language freely (art. 68). Also includes the right to receive education in their own language (art.68), and the right to promote language... (art. 68).

56 The current Constitution states in Article 8 that Gaelic is the first official language and English the second. For this reason the Irish is a compulsory subject in the Republic, though English is in reality the dominant language of education, for the Charter the Gaelic is a «less widely used oficial language». The Constitution refers to a subsequent law that regulates the status of languages (art. 8). Likewise the Constitution refers to a subsequent law that regulates the status of languages (art. 8). Those are the reasons that causes that in the Constitution there are included the terms of national language and official language.

57 Date of signature: $27 / 06 / 2000$. Roma has been excluded from protection. Italy is a nation with a highly decentralized territorial organization, in which there are at least twelve 


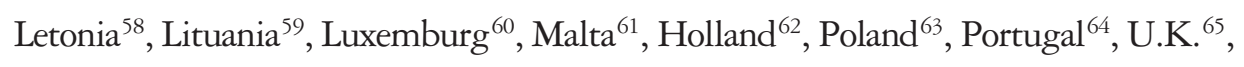

recognized minority languages. The Italian Constitution does not allow discrimination on linguistic grounds (art. 3), and the article 6 refers to all the linguistic minorities existing in the country.

58 Livonian; Russian; and Roma have been excluded from protection. The Constitution offers protection to the minority languages, and guarantees the right to use own language freely (art. 114). Also includes an official language in the article 4. The Law of languages of Latvia qualifies as autonomous population language the liv language.

59 Livonian; Russian; Polish; and Roma have been excluded from protection. The Lituanian Constitution does not allow discrimination on linguistic grounds (art. 29), and the protection of linguistic minorities is granted, as well as other rights; the right to promote language (art. 37). It recognizes the existence of a State language (art. 14).

60 Date of signature: 05/11/92. Ratified on the 22/06/2005. In force since the 01/10/2005 In 1923 Luxembourg was the venue for the first International Conference on bilingualism sponsored by the International Bureau of Education. The Constitution does not includes any language question. Only refers to subsequent laws that regulates the status of languages (art. 29); the 1984 Law on language includes the national language.

${ }_{61}$ Date of signature: 05/11/92.

62 Date of signature: 05/11/92. Ratified on the 02/05/96. In force since the 01/03/98. Protected minority languages: Friesian (used in Friesland) Low Saxon; Roma; and Yiddish. The Constitution does not mencioned linguistic question.

63 Date of signature: 12/05/2003. Roma and Kashubian are excluded from protection. The Polish Constitution does not allow discrimination on linguistic grounds (art. 233), the protection of linguistic minorities is granted and guarantees the right to use own language freely (art.35), as well as other rights; the right to promote language (art. 35). Includes official language (art. 27).

64 Mirandes is a protected minority language. Roma is unprotected. The Portuguese Constitution does not allow discrimination on linguistic grounds (art. 13), and includes official language (art. 11).

65 Date of signature: 02/03/2000. Ratified on the 27/03/2001. In force since: 01/07/2001. The United Kingdom is composed of three nations, England, Wales and Scotland. English is spoken in England, Welsh in Wales and Scottish Gaelic in Scotland; in practice English is the majority language around the UK, though in both in Wales and Scotland a minority of the population speak both languages as their mother tongue. In the case of Wales 20\% of the population, which comes to represent approximately half a million people, claim Welsh as their native language. With respect to Scotland, only about 100,000 people, dominate Scottish Gaelic, the majority of whom live in the Highlands and in the Hebrides. The 1970s witnessed an increasing awareness of the importance of preserving the Scottish Gaelic, given the very real risk of its disappearance as a living language. Roused by Executive inaction, a group of parents were at the forefront of a movement to put Gaelic into the school curriculum. Protected minority languages : Cornish (used in Cornwall, England); Welsh (used in Wales) Scottish Gaelic (used in Scotland); Irish (used in Northern Ireland); Scottish (used in Scotland and Northern Ireland). Spanish (Gibraltar) or Roma are not protected. The British Constitution does not include any language question, but the 1998 law about the Wales Government, in the 47 article says that welsh and english have the same legal status. 
Rumania ${ }^{66}$, Sweden ${ }^{67}$.

Member States that sign and proceed to ratification are under an obligation to implement the provisions contained in Part II of the document, to those regional or minority languages that meet the provisions of Article I (i.e. that they are spoken by a small number of people, are not the official language, and are spoken within the territory of the state). This commitment means that Member States recognize that regional or minority languages are an expression of cultural wealth, and are therefore under an obligation not only to safeguard them, but also to promote their study at all levels of the state education system, including adopting policies aimed at promoting interstate student exchanges, and endeavoring to minimize inequality between minority languages speakers with the rest of the state population. In accordance with Part III, Member States have to determine to what languages these provisions will be applied.

In the case of the Spanish State, at the time of ratification, it was stated that it would be applied only to those languages specifically declared official in the Statute of Autonomy of the Basque Country, Catalonia, the Balearic Islands, Galicia, Valencia and Navarra. Aranese was declared an official language for the first time in the Catalan Autonomy Statute of July 2006, so the provisions of Part III apply. Spain has also acknowledged that there are also other languages that have protected status under statute law as a result of repetitive use, and therefore are considered minority languages: as is the case of Galician under the local statutes of Castile and León (pursuant to Article 74 it is considered a protected language) and in Extremadura; the Catalan and Aragonese (Fable)

66 Date of signature: 17/07/1995; ratified on the 29/01/2008. In force since the 01/05/2008. Protected minority languages include : Albanian, Armenian, Bulgarian, Czech-Croatian, Croatian, German, Greek, Italian, Yiddish, Macedonian, Hungarian, Polish, Roma, Russian, Ruthenain, Serbian, Slovakian, Tartar, Turkish and Ukrainian. The Rumanian Constitution does not allow discrimination on linguistic grounds (art. 4), and the protection of linguistic minorities is granted. The right to preserve the linguistic identity is also included in the Magna Carta (art. 6), with the right to receive education in their own language (art. 32). Likewise the Constitution refers to a subsequent law that regulates the status of languages (art.32), but includes an official language (art. 13).

67 Date of signature: 09/02/2000. Date of ratification: 09/002/2000. In force since the 01/06/2000. Protected minority languages: Sami (it is considered the official language in some municipalities or districts); Finnish (it is considered the official language in some municipalities); Meänkieli; Roma; Chib; Yiddish. The last two are not linked to any territory. Although the Constitution does not declare any language official, it is clear that the majority language is Swedish, although it coexists with other minority languages considered, such as Finnish, spoken today by about 460,000 people in a state of nine million. The Swedish Constitution does not allow discrimination on linguistic grounds (art. 8), and the protection of linguistic minorities is granted. As well other rights are regulated; the right to promote language (art. 2). 
languages in Aragon; Asturian (Bable), and Asturian/Galician in Asturias; and Leonese in Castile and León.

The Committee of Experts of the Council of Europe periodically prepares a status report on the implementation of the European Charter in each of the signatory states, in terms of the specific control mechanisms in place; these can be based on requested documentation from the authorities, as well as information that is sent by independent bodies working on the matter and who are knowledgeable about the real situation on the ground as regards the languages. The purpose of this is to test, analyze and evaluate the way in which the Charter is being applied in each Member State; the actual situation as regards the protected target language; the progress being made and recommendations to be taken in terms of measures to promote both legislatively, and at a political level a greater degree of protection for the minority languages under consideration. Should the picture not be clear enough in any aspect, Member States may be required to provide all the information necessary to clarify the situation. Furthermore, and in order to complete the study, delegations are sent to Member States to meet with people and institutions familiar with the situation on the ground, in order to obtain more comprehensive information concerning the language, and to establish those points necessary for improved protection. The government of each Member State is in due course provided with the report, not only to make them aware of the situation and to implement the recommendations included in it, but also to provide information to citizens and other Member States alike about the degree of protection given to minority languages in each country evaluated.

The final report prepared by the Committee of Experts of the Council of Europe on the implementation of the Charter in Spain, has included a number of recommendations - in accordance with the provisions of the third paragraph of Article 16 - to be taken into account by the Spanish authorities with regard to the adoption of policies on regional or minority languages. The reports periodically conducted by the Committee, have noted that apart from the languages protected under the Statutes of Autonomy, other tongues routinely used by certain sectors of the population lack any such legislative recognition or protection; this is the case with Valencian in Murcia, Tamazight (Berber) in the Autonomous City of Melilla and Arabic in the Autonomous City of Ceuta.

In Melilla, the Tamazight language was used by the indigenous people before the territory became part of the Spanish state. Despite this, it is not considered an official language and is not taught in schools, though it is on offer in adult centers of education. The Committee has endorsed its protection, and that the authorities encourage its dissemination. Another language mentioned 
in the report is Roma. An investigation into its use has been requested. There is evidence that while the original Roma is no longer spoken, nevertheless a mixture of Roma and Castilian is still in use.

As regards the spread of the Spanish language and the other languages protected by the Statutes of Autonomy among foreign citizens living abroad, Law 40/2006, of 14 December has been passed. This establishes a policy of collaboration between the State and Autonomous Communities in order to facilitate education and access to the Castilian and the other co-official languages, both for the Spanish and their descendants; to achieve this bilateral and multilateral agreements have been signed with other States.

Therefore, and because not all minority languages have the same status and level of protection, the second report issued under the Charter has recommended that the Spanish authorities clarify and determine their status, in order to promote and protect their use, without neglecting the interests of speakers. Other languages, which experts also view as unprotected in Spain is the Portuguese spoken in the regions of Castile and León and Extremadura; according to experts it is traditionally used in the municipalities of Bouza and Alamedilla in Castile and León, the Jálama Valley, Herrera de Alcántara (although its use today is negligible), Cedillo and in the border region of Valencia de Alcántara and Codobera (in this region Portuguese has been commonly used since the eighteenth century), in Olivenza and in Extremadura. Olivenza belonged to Portugal until the nineteenth century, although at present according to expert opinion there is no data to support its continued use.

Another language is Darija (a variety of Arabic spoken in the Autonomous City of Ceuta), whose use is a consequence of migration the city has experienced from the neighboring Alawite kingdom; if this is the case then it cannot be considered a minority language as such, given that according to expert opinion it is not a language traditionally used in this region by the local inhabitants, though at present it is in common use with about forty-five percent of the population. Its use has gradually increased since the beginning of 1970s, when the North African population in the area was only ten percent. Given the extent of its use, and evident character as imported with increased immigration, and despite the legislative reality that languages used by immigrants cannot be considered minority languages, even so the Committee has recommended that the Spanish authorities conduct a thorough study of its linguistic status in the area, given that the Committee takes the view that the obligation to promote and protect minority languages is independent of the place of birth of their speakers. (ECRML (2001) 3. 
The competent authorities periodically evaluate the policy undertaken by the various Member States, who are obliged to provide public reports, which should reflect all measures taken to promote the protection and survival of these minority languages.

The Universal Declaration of the Collective Rights of Peoples was approved in Barcelona in May 1990. This document states that all peoples have the right to express and develop their culture, language and rules of organization, to which end they are to be provided with educational policies ${ }^{68}$, and the creation of institutions to enable the development of such rights.

We cannot fail to mention the Final Declaration adopted by the General : Hungarian city of Pécs (16.08.1991), which makes a recommendation to the authorities that language rights be included among the fundamental rights of individuals, which would insure them acquiring the maximum levels of protection and security, both internally within States, and internationally, so that the treatment given to this right would be quite distinct different at both levels.

The Santiago de Compostela Declaration of Postsecondary Education Network (PEN) International and the 1993 Declaration of the Translation and Linguistic Rights Committee of (PEN) stress the urgent need to summon a World Conference on Linguistic Rights.

On 10 November 1994, the European Union through the Council of Europe adopted the Framework Convention for the Protection of National Minorities ${ }^{69}$ (that has been available for signing by the member States of the Organization for Security and Cooperation in Europe OSCE ${ }^{70}$, since February 1, 1995). The Convention, despite lacking an explicit definition of what is meant by a minority, involves the imposition of targets to be achieved by the Member States, while leaving it to the States themselves to determine in what way they will apply the obligations imposed upon them. The Convention does not amount to a Bill of Rights but in the third provision it enshrines the individual right to be treated as a person belonging to a national minority. Specifically Section II, article $4^{\circ}$ paragraph 2 provides that:

«The signatories shall proceed with the adoption of all possible measures relevant for achieving an optimum degree of equality between persons comprising

68 MILAN I MASSANA, A., Derechos lingüísticos y derecho fundamental a la educación. Un estudio comparado: Italia, Bélgica, Suiza, Canadá y España. Civitas. Madrid. 1994.

69 See VVAA: Derechos de las minorías y de los grupos diferenciados. Escuela Libre. Madrid. 1994.

70 HOLT, S., and PACKER, J., «OSCE Developments and Linguistic Minorities» in UNESCO Most Journal on Multicultural Societies, vol. 3, n. . 2. 2001. 
a minority located in their territory, fully respecting their own identities, which shall not be prejudiced in any way, in order to attain such equality.»

The following articles oblige the signatories to promote the adoption of such measures as are appropriate to achieve a climate of respect and agreement in sensitive cultural and educational areas.

The Universal Declaration of Linguistic Rights ${ }^{71}$ was signed in Barcelona from the 6 to 9 of June $1996^{72}$. The signing was conducted by local nongovernmental advocates of unrecognized languages in formal education, such as international NGOs, legal experts, linguists ${ }^{73}$, and was based on numerous international declarations and resolutions, calling for the need to eliminate linguistic imbalances and to achieve respect and full development for all languages, regardless of the regulatory framework governing them and irrespective of whether or not they enjoy official status. The motivation behind the Declaration did not come from government organizations nor from national States, but rather from the linguistic communities themselves, who were all too aware of the disadvantage in which some minority languages have found themselves. The document begins with a definition of what is meant by a linguistic community and notes that this is rooted in all settled human societies in a given territory, regardless of whether that territory has been recognized or not, and is embodied in a population aware of their own identity who have developed a common language through which they communicate, and that plays an important role as a means of achieving cultural cohesion. The Declaration recognizes - as does the Charter of Regional and Minority Languages — the individual and collective character of linguistic rights ${ }^{74}$ and that the latter include the right to education in their own language and culture.

71 Monitoring Committee of the Universal Declaration of Linguistic Rights. April 1998. Producción: Institut d'Edicions de la Diputació de Barcelona.

72 See VVAA: Las políticas linguiísticas a partir de la Declaración Universal de los Derechos Lingüísticos (III Simposio Internacional de Lenguas Europeas y legislaciones). Ciemen-Editorial Mediterránea. Barcelona. 1988.

73 From the June 6 to 81996 in Barcelona 61 NGOs, 41 PEN centers, and 41 experts on linguistic rights worldwide were gathered together. The initiative for the convening of the World Conference on Linguistic Rights (CMDL) emerged from the Translations and Linguistic Rights of PEN International and CIEMEN (International Centre for Ethnic Minorities and Nations), with the support of UNESCO . The Assembly established the Committee for Monitoring the Declaration who are charged with task of monitoring the passage of the text within UNESCO.

74 The problem of the recognition of collective rights is that of their legal articulation, viz. the question to whom is the right of action given before the courts. Note that the Spanish Constitution of 1978 in Article 9.2 states that «it is up to the public authorities to promote the 
The Oslo Recommendations Regarding the Linguistic Rights of National Minorities $\mathcal{E}$ Explanatory Note, recommendation was passed by in February 1998 by the Organisation for Security and Co-operation in Europe (OSCE). As commentators have noted ${ }^{75}$, this exposes the low level of protection afforded to minorities in Europe, among other things, due to the lack of definition of public and private spheres. The Recommendation obliges States to carry out the educational policies that promote the study of minority languages and their dissemination through the media, with the aim of reaching broader sectors of the population, who would otherwise remain outside contact with these largely unprotected languages.

The Council of Europe, in the course of celebrating its fiftieth anniversary in Budapest in May 1999, initiated the «Minorities of Europe» program in collaboration with the European Union.

The Congress of Local and Regional Authorities of the Council of Europe, March 18, 2010 (301/2010) on Minority Languages in highlighting the positive benefits of achieving increased regional development, stressed the existence within this context of vernacular languages as greatly enriching their defining character.

\section{CONCLUSIONS}

The protection of minorities in Europe is a relatively recent phenomenon ${ }^{76}$. When the EEC was founded the authorities avoided approving regulations specifically aimed at protecting minority rights, the objectives at the outset of the EEC were mainly of an economic nature, later moving on to achieve purely

conditions for freedom and equality of individuals and of the groups to which they belong in a real and effective manner». Clearly, the Constitution imposes a duty on the part of the state to act for both individual and the groups in which they are integrated, but the precise mechanisms are not laid down to compel the State to establish the necessary mechanisms to promote freedom and equality; nor is it clarified what is the level of action that is considered sufficient to comply with the constitutional mandate.

75 SEE PLÁ COELHO, R.J., «La diversidad lingüística desde un enfoque jurídico en Europa-Reflexiones sobre la elaboración de un catálogo mínimo de derechos de la lengua por los derechos internacional y comunitario», in Diáleg-Diversitat lingüística, sostenibilidad i pau. 21 of May. Forum Barcelona. 2004.

76 AMÓN CHORNET, C., «El Derecho Internacional ante las reivindicaciones de las minorías lingüísticas», in Anuario de Derecho Internacional, n. ${ }^{\circ}$ 19. 2003. Págs. 409-414. Interesting work that carried out a review of the relation ship international light-linguistic minorities. 
political goals, in these circumstances issues relating to minorities were very much of secondary importance.

It was not until the adoption of the Maastricht Treaty when attention was drawn to the fact that there existed within the Union a multitude of minorities who were unprotected, in the light of which the community institutions have become increasingly aware of the need to adopt measures to foster care for the existing diversity. Language diversity within the European Union is a fact and different institutions have been sounding the alarm that certain languages are in serious danger of disappearing unless appropriate measures are taken with regard to their protection and promotion.

EU Institutions that have demonstrated a degree of awareness towards minority languages as an expression of multiculturalism in the Union include the Parliament, which has promoted educational policies designed to promote the study and dissemination of culture and minority languages at all educational levels, by creating specific institutions in order to emphasize the need for their protection ${ }^{77}$. In this task the Parliament has not been alone, as the Commission too has jointly acted, clearly showing its commitment to the existence of languages as community assets. The Committee of the Regions has also played a key role in the promotion and dissemination of European languages. From a policy perspective it is possible to highlight a number of fundamental regulations that have unquestioningly supported language protection. In this sense, as mentioned above, the Maastricht Treaty marks a significant turning point with regard to the recognition of the role played by languages in the European framework. Likewise another important document is the Charter of Fundamental Rights (2000), to which the Lisbon Treaty refers in Article 6, the provisions of which determine that the Union recognizes the rights, freedoms and principles contained in it, and bestows on its provisions the same legal status as the Treaties. Articles 21 and 22, are critical to determining the respect accorded to cultural diversity irrespective of whether it be religious or linguistic.

For its part, the Council of Europe has played a key role as the European Charter for Regional or Minority Languages, is the document that grants protection to all those languages used in the Member States that lack official status. Nevertheless much work still remains to be done, as it is for the Member

77 ARCINA, GONZÁLEZ DE VEGA, MARIÑO, PETSCHEN, DE PUIG, RUIZ VIEYTEZ and SOROETA (ED.): Cursos de derechos humanos de Donostia-San Sebastián. Vol. I: Derechos de las minorías. UPV. 1999. This written work analyzes the protection afforded by international law of minorities. 
States, in the exercise of their sovereignty to implement policies that will govern to a greater or lesser degree the protection of regional languages within their respective borders.

Title:

THE PROTECTION OF MINORITY LANGUAGES AT THE EUROPEAN LEVEL

\section{Summary:}

1. Introducción. 2. La protección de las lenguas minoritarias en la Unión Europea. 3. La protección de las lenguas minoritarias fuera del marco de la Unión Europea. 4. Conclusiones.

\section{Resumen:}

La diversidad lingüística existente en el seno de la Unión Europea supone una expresión de la multiculturalidad y de la pluralidad que no es sino la base de la Europa actual. Es por ello que desde las instituciones han sido adoptadas distintas normativas tendentes a la promoción, conservación y protección de la lenguas utilizadas por los ciudadanos comunitarios, especialmente de las denominadas regionales o minoritarias, ya que si bien es verdad, que esta protección ha de ser llevada a cabo por los propios Estados miembros, las autoridades comunitarias han dado pasos decisivos en aras a garantizar la no desaparición de las lenguas que enriquecen la idiosincrasia tanto de los Estados como de la propia Unión. La protección en el ámbito comunitario de las minorías no supuso en los indicios de la andadura comunitaria un hecho prioritario, pues en aquellos primeros momentos se incidió en otros aspectos, como el económico o el político que se consideraron más importantes. Sin embargo, con la entrada en vigor del Tratado de Maastricht se produjo un cambio significativo en este aspecto, ya que el reconocimiento de los derechos de las minorías va a convertirse en una realidad. Desde entonces se va a incidir mucho en su protección como queda patente en el tratamiento que de él hace la Carta de los Derechos Fundamentales o el Tratado de Lisboa. En este trabajo vamos ha hacer un recorrido por la evolución que ha sufrido la protección de las minorías lingüísticas en el ámbito comunitario, sin olvidar la labor realizada en el seno de otras instituciones extracomunitarias, como es el caso del Consejo de Europa entre otras, sin cuya labor no se hubieran alcanzado los niveles de protección de las lenguas minoritarias existentes en la actualidad. 


\begin{abstract}
:
The linguistic diversity within the European Union is an expression of the multiculturalism and plurality which is the basis of today's Europe. That is why the EU institutions have adopted various regulations aimed at the promotion, preservation and protection of the languages used by EU citizens, especially those of so-called regional or minority groups. Though implementing this protection is delegated to Member States themselves, the EU authorities for their part have also taken decisive steps in order to ensure the continued health of the languages that enrich the idiosyncrasies of both the Member States and of the Union itself. While the protection of minorities at a Community level was not an initial priority at the outset of the EU given the greater importance of economic and political considerations. However, with the entry into force of the Treaty of Maastricht there has been a significant change in this respect; the recognition of minority rights has now become a reality. This recognition is now given due consideration as evidenced by the provisions of both the Charter of Fundamental Rights and the Treaty of Lisbon. This paper has outlined the progress that has been made in the protection of linguistic minorities at the EU community level, without forgetting the work within other extra-Eu institutions, as it is the case of the Council of Europe, among others, without whose work the levels of protection of existing minority languages not have reached today.
\end{abstract}

\title{
Palabras clave:
}

Lengua minoritaria, Unión Europea, Consejo de Europa, Tratado de Maastricht, Carta de Derechos Fundamentales.

Key words:

Minority language; European Union; Council of Europe; the Maastricht Treaty; Charter of Fundamental Rights. 